\title{
Negotiating Representation of Islamic Values on Korean TV Dramas Among Indonesian Muslim Youth
}

\author{
IMRON ROSIDI \\ KHOTIMAH \\ State Islamic University of Sultan Syarif Kasim Riau, Indonesia
}

\begin{abstract}
This article describes one of the effects of globalization on young Muslims in Indonesia. They interact with a variety of cultural products from all corners of the world. Focusing on Indonesia, this article argues that the emergence of globalization has provided opportunities for young Muslims to negotiate Islamic value representations of Korean TV dramas. Using ethnography method, this article selects young Indonesian Muslims who like Korean television drama as informants. The emergence of transnational cultural products was believed to play an important role in the process of 'cultural imperialism' among young people. The information and views presented are not considered to be a 'healthy' menu for Muslim youth. In fact, in cultural studies, media imperialism or cultural imperialism is famously contested. By interviewing and observing 42 informants, this article finds that Muslim youth do not receive all the messages from the media passively. During their consumption on Korean television dramas, young Muslims are negotiating their representations. They are capable of selecting values from the television dramas. These Muslim consumers in this context do not just accept all the messages and representations of Korean television dramas. Indonesian Muslim youth have an innate cultural identity and conscious knowledge, which they have obtained from their learning environments such as education and culture. Muslim youth interpret "stories" in drama by relating them to their Islamic values.
\end{abstract}

Keywords: Negotiation, representations, Islamic values, youth, Korean TV dramas.

\section{INTRODUCTION}

The popularity of Korean TV dramas in Indonesia is influenced by media globalization. Globalization supports Indonesian people to easily access cultural products from other countries, including from South Korea. The popularity of Korean drama in Indonesia is thus in effect influenced by the popularity of Korean dramas in other countries. It is no wonder that the popularity of Korean has been described as Korean Wave due to its global phenomena. This term, according to Ravina $(2009$, p.3), refers to a flow of Korean cultural products to various countries which mainly consist of Korean TV dramas and Korean pop music as well as Korean movies.

The rise of Korean TV dramas in Indonesia cannot be separated from the issue of cultural imperialism. This is because globalization has provided 'foreign' cultural products such as Korean TV dramas to be consumed by local audiences. Their images and representations to some extent have different values which may endanger local and religious values of audiences. In fact, they are popular among Indonesian Muslim youth. This article then seeks to know the reception of young Muslim in Indonesia on Korean TV dramas. It especially focuses on their views and responses on Islamic value representations mediated through Korean TV dramas. 
This article believes that the reception of Korean TV dramas among Indonesian young Muslims can be seen as counter-cultural imperialism. The popularity of Korean TV dramas in Indonesia indicates that media globalization is not a monolithic one-way flow from the West to the rest. Indonesian youth fascination with Korean television dramas supports the multiplicity of the global media industry. Youth media consumption is not dominated by the West. Indonesia has been open to foreign cultural products including from East Asian countries. Therefore, this study argues that the presence of Korean pop culture co-exists side by side with US domination in the global media industry.

This article argues that young Muslims in Indonesia who consume Korean TV dramas are not passive viewers. Their culture is not dominated and controlled by Korean culture mediated through Korean TV dramas. These youth actually negotiate representation of Islamic values on Korean TV dramas. In this case, Islamic values refer to values which are considered Islamic by Muslim youth. They learn the values from family, school or university and community. These values may include positive ones which are actually taught by other religions and cultures. Hard work, for instance, is regarded as part of Islamic values by young Muslims. In fact, it is also part of Korean culture as represented on Korean TV dramas.

\section{LITERATURE REVIEW}

Studies on Korean TV drama are plentiful. Chua (2008) for example examines foreign elements in the appearance of Korean dramas as one of the important factors in which the audience is attracted to Korean dramas. However, a study conducted by Ida (2008) shows that the concept of 'cultural proximity' has a role in driving the popularity of Korean drama in Indonesia. However, Lu, Liu and Cheng (2019) finds that cultural proximity could not explain the enjoyment of Chinese audiences consuming Korean TV Dramas. Ng and Chang (2019) confirms that Hong Kong audiences do not get a high impact from Korean TV dramas. This is based on their moderate behavioural intention travelling to Korean tourism destination represented on Korean TV Dramas. Han (2019) also argues that cultural proximity is no longer a determinant factor for the popularity of Korean TV Dramas in Latin America. A number of the above studies start their argument based on cultural proximity theory. They do not focus on cultural imperialism theory to explain the popularity of Korean TV dramas in Indonesia.

However, some scholars studying Korean pop culture in Indonesia argue that cultural imperialism disseminated through Korean cultural products has been visible among young Indonesians. Astuti (2012) finds that Korean pop culture disseminates Korean cultures among Indonesian youth which endanger Indonesian cultures. She then confirms that cultural imperialism fits with her study finding. Dwihadiah (2015) supports cultural imperialism theory in her study about K-Pop fans in Indonesia. She discovers that Korean cultural hegemony is disseminated through social media and websites among young Indonesians. Putri and Reese (2016) suggest that Korean TV dramas have successfully influenced to Indonesian youth. Their study catches that Korean TV dramas alter Indonesian youth's mind and behaviour. The above studies mainly focus on Indonesian youth living in Jakarta and its surrounding areas. Jakarta and its contiguous zones have plural populations which have different cultural and religious backgrounds. In fact, they do not select purposively young Muslims to be their informants. The impact of media products such as Korean TV dramas might be different to young Muslims.

In this global communication, the significant attention is paid to the rise of transnational cultural products which are connected to the notion of cultural imperialism. Chopra (2011, p.4) argues that "the "cultural imperialism" theory is a natural starting point for any discussion of global media." The engagement of cultural exchange within the global 
world is characterized by the debate of the cultural imperialism which has been known among scholars over the last several decades. The notion of cultural imperialism is embodied by the domination of Western countries, mainly the USA, in exporting television programs and motion pictures to developing countries including Indonesia. Furthermore, their television programs have been suspected of transferring immoral values in society, especially for the youth. Parents concern that their cultural identities can be influenced by foreign cultural values. This is because these foreign cultural values have been regarded as in opposition to their own values. Tunstall, as cited by Tomlison (2001, p.8), states "the cultural imperialism thesis claims that that authentic, traditional, and local culture in many parts of the world is being battered out of existence by the indiscriminate dumping of large quantities of slick commercial and media products, mainly from the United States."

The notion of cultural imperialism proposes an important discourse in which it emphasizes that globalization is a process of cultural homogenization. It is characterized by the global cultural flows which are represented by one-way traffic. This one-way traffic is dictated by the flow of cultural discourse from the West to East and North to South. This notion also views that globalization marked by the opening of cultural exchange opportunities and the dissemination of foreign cultures, especially from the West, has resulted in a homogeneous culture. In fact, in cultural studies, there are some disagreements about the homogenization of culture as the impact of globalization. They are basically intended to criticize against the reduction of globalization as Americanization. The notion of cultural imperialism is also under critical assessment because it put forwards that one culture can be dominated by another. Appadurai argues $(1998$, p.17) that "globalization does not necessarily or even frequently imply homogenization of Americanization".

The fear of cultural imperialism has led to the notion of cultural protectionism. Oh (2017, p.253) states that Korean TV dramas in Indonesia "ignited internal worries among male Islamic groups of the nation who want to curtail female Hallyu fandom in their country to protect Islamic fundamentals". In this case, local culture has been regarded to be protected from foreign cultural products imported. Abdul Shomad, a famous Islamic preacher in Indonesia, forbids young Muslims consuming Korean TV dramas by claiming that those who remain consuming them are infidels (Astuti, 2019). In fact, Pawanteh, Rahim and Ahmad (2009) argue that media is not the only factor affecting cultural change in society (p.30) including young Muslims.

Monaco (2000, p.48) states "there have never been pure cultures just as there have never been pure ethnic groups or races." This indicates that all cultures have not been 'original' because, throughout history, elements from other cultural sources around the world have characteristically been absorbed and indigenized. Storey (2000) also rejects the notion of cultural imperialism by proposing four reasons. The first reason is that he rejects the notion since economic commodities and culture are different things. People may use certain commodities from other countries but it does not mean that their indigenous culture can be destroyed and dominated. The second reason is that people are not a passive consumer. He believes that the dominant globalizing culture will not be easily injected into consumers. The third reason is that there are now many centres of power in the world, not only America. The rise of Korean pop culture for instance certainly challenges the notion of globalization as Americanization. The fourth reason is that globalization as Americanization rejects the fact that American culture is basically never monolithic. 
This article believes in the active position of youth. They are not ' passive recipients of culture'. In cultural studies, cultural consumption is considered as creative consumption - as stated by Barker (2000, p.46). This means that the "meaning" received by the public is not monopolized by the producer or the people who make the message. Consumers or audiences actively interpret the meaning sent; because the text that is circulated by the manufacturer is " polysemic ". Cultural products like music, movies, and television produced by company "capitalist " but the meaning is always contested by the consumer or audience. The audience has the ability to be selective about the meaning sent. The active role of consumers in negotiating the " meaning " sent by cultural texts is supported by Goodman and Cohen (2004, p.2-3) who suggest that consumption is not merely the acquisition of the meaning of a predetermined product. Consumption is not a one-way process but a process of negotiation and contestation.

Therefore, this study emphasizes that young people are actively negotiating the representations of Korean TV dramas. This means that their comments and opinions about Korean TV dramas are very important in this research to provide research findings.

\section{METHODOLOGY}

The central concern of this study is the Indonesian youth engagement with Korean pop culture, specifically Korean television drama. Previous scholars conducting this research have used two different methodological types of research. They are quantitative and qualitative methods. The first is usually done by using surveys while the latter is conducted by employing interviews and observation. This article employs a qualitative method specifically ethnographic study. This, according to Takahashi (2010, p.65), has emerged against the dominant methodological approaches of textual determinism and behaviourism's psychological reductionism. The main advantage of using ethnography is that an ethnographical study is able to account and reveal the diversity of the audience's interpretations of media.

Hammersley and Atkinson (2007, p.7-8) state that quantitative method is developed by positivist proponents where they promote the status of experimental and survey research and the quantitative forms of analysis associated with them. In some cases, during the nineteenth century, some sociologists and social psychologists used both qualitative and quantitative data as complementary. Later, with the growing and rapid development of a statistical method, the survey has been viewed as a 'self-sufficient' methodological tradition. Furthermore, positivist proponents put forward that it is only through the use of physical or statistical control of variables, and their precise measurement, that science is able to construct a body of knowledge with a conclusive validity; and thus can justifiably replace the myths and dogma of traditional analysis or common sense. In fact, naturalist proponents regard that social phenomena are quite different in character from physical phenomena. They also argue that the social world cannot be understood in terms of simple causal relationships or by the inclusion of social events under universal laws because human actions are based upon, or infused by, social or cultural meanings: that is, by intentions, motives, beliefs, rules, discourses, and values.

Storey (2003, p.130) suggest that "cultural studies ethnography is not a means to verify the 'true' meaning or meanings of 'text'; rather, an ethnographic investigation is undertaken as a means to discover the meaning people make; the meanings which circulate and become embedded in the lived cultures of people's every day". Thus, it is hoped that the research would provide a useful balance to the results of quantitative approach which usually 
uses surveys. While quantitative method usefully details the overall pattern of Indonesian youth' responses toward Korean television drama, it cannot hope to explain why these responses are made. Furthermore, the complexity of audience's responses to media messages has led some scholars to the 'ethnographic turn' so that many researchers have conducted ethnographic studies of particular occurrences of media consumption and discovered involved knowledge about the process (Milestone \& Meyer, 2012, p.152).

In this article, forty-two young informants are chosen for an ethnographic study. They are selected purposively based on two important characteristics; they love consuming Korean television dramas and they are Muslim youth. The first characteristic is clear here since this research is to identify youth consumption on Korean television dramas. The second characteristic is imperative because, for Muslim scholars, Muslim youth should be protected from Korean pop culture influences. Therefore, studying these Muslim youth is crucial to identify their agency regarding their consumption on Korean television dramas. They are selected on the basis of friendship links in which their voice is important to hear regarding their hobby on consuming Korean television dramas.

This article is based on observation and in-depth interviews among twenty-one young Muslim informants in Pekanbaru and twenty-one young Muslims in Padang. Their age is from 16 to 30 years old. From forty-two informants, thirty-one informants are females while ten of them are males. The first fieldwork was conducted from May to June 2018 and the second one was done from May to June 2019. These two cities are selected as the place of study because they reflect the towns preserving local and traditional norms. In both cities, Islam is fundamental so that the public sphere is filled with Islamic symbols. Islamic $d a^{\prime} w a$ (prolysitizing) is disseminated intensively in mosques, schools, offices, universities and communities. It is mainly in the form of 'wirid' (oral preaching) done by ustaz. The preaching themes are varied but they occasionally invite young Muslims to keep Islamic values by rejecting 'foreign' culture disseminated by transnational media such as Korean TV dramas and Hollywood movies.

Pekanbaru, the capital city of Riau Province, is a home for relatively plural populations while Padang, the capital city of West Sumatra, is a town dominated by Padangese people. These two towns have a famous proverb "Adat basandi Syarak, Syarak basandi Kitabullah" (Custom is based on Islam, Islam is based on Qur'an). This proverb indicates the strong commitment of local people in these two cities to keep Islamic values. In Pekanbaru, there is actually no specific Islamic regulation issued by the local government. However, the activities of Islamic $d a^{\prime} w a$ are very active seen from the presence of two active $d a^{\prime} w a$ organizations, namely IKMI (Indonesian Mosque Association) and MDI (Islamic Da'wa Assembly). Every week, these organizations send their preachers to be khatib (Jum'at preacher) to all mosques in Pekanbaru. They also send their preachers when a mosque or community needs a preacher for the wirid activity. This wirid is mostly done every week at night or afternoon. Padang, however, has multiple Islamic regulations (Salim, 2015). These Islamic regulations were issued to protect Islamic values from foreign cultural influence. Under Islamic regulation on behaviour and dress, two striptease dancers at the Cafe and Resto Fellas in Padang were arrested and jailed for one and half year (Salim, 2015, p.150). 


\section{RESULTS AND DISCUSSION}

Since the early 1990s, the notion of cultural imperialism has been criticized from various perspectives (Pieterse, 1995; Storey, 2003). The global media flows are no longer one way. The global media flows have been characterized by their plurality of actors. The emergence of some cultural industries from different parts of the world such as Asian and Latin American broadcasting companies can be seen as the best examples here. Furthermore, in recent years, the rise of Korean TV dramas in Indonesia could be viewed as counter-cultural imperialism. This is because Korean TV dramas have been able to attract their consumers in East and Southeast Asian countries, including Indonesia. These television dramas have been able to challenge the notion of cultural imperialism since it supports the fact that the global media flows are not only one way, namely from the West.

The rise of Korean TV dramas has been identified as cultural products challenging Western cultural force which changes the dynamics of the media landscape in the region. Indonesian youth compare to Western cultural products which sometimes depict erotic display. As it was known, Indonesia has been open to foreign cultural products including from the West. Indonesian youth fascination with Korean television dramas is due to the reason that Indonesian youth are bored with the cultural products from the West since they mostly portray many elements of foreignness on their representations. Western cultural products which depict sexuality are considered in opposition with Islamic values while Korean television dramas tend to accommodate some of their own values and culture. This can be seen from the representations on Korean television dramas which are close to their social and cultural experiences such as respecting older people and family relationship. Another problem of cultural imperialism lies on its assumption that the media have unavoidably straight, great and influential effect on their audience. Herbert Blumer as quoted by Defleur and Ball-Rokeach (1989, p.216) states "both children and adults acquire attitudes, emotional responses, and new styles of conduct from all the media, and especially from films and television." This idea was basically based on the perspective that audiences create certain behaviour after receiving certain stimulus from media. This assumption is criticized within the cultural studies tradition which regards that audiences are not cultural dopes but active producers of meaning from their own cultural context. This is developed in reaction to the view that consuming television programs is passive in nature in which meanings and messages of cultural texts, in this case, television programs are automatically filled in by audiences. In fact, audiences are active creators of meaning in relation to television programs. They do not simply accept the meanings sent by cultural texts (Barker, 2000).

Young Muslims are critical on Korean cultural products since the story which seems 'foreign' among Indonesian audiences is commonly found. This can be seen from the story portrayed on a Korean television drama entitled 'Full House'. This Korean TV drama was broadcasted in Indonesian television channels several times indicating that this TV drama has been popular among Indonesian viewers. In 2005, for instance, it was screened on Indosiar, in 2015, it was broadcast on RCTI, and in 2017, it was re-broadcast on GlobalTV. This drama is also available on YouTube which can be watched every time and everywhere by Indonesian young Muslims. Consisting of 16 episodes, this drama tells about a woman named Han Ji- Eun and a man named Lee Young-Jae who got a contract married for one year. According to young Muslim audiences in Padang, in this drama, the relationship built between a male and female actor is not 'Islamic' since they get married based on certain time contract. An informant, Nanda, expresses: 
"In Islam, we should get married for a lifetime. Yes, if there is a problem during the marriage, one can ask for a divorce. But there is no contract marriage in Islam" (Personal interview, May 25th, 2018).

However, she acknowledges that in this drama there are some values which are suitable to Islam. Nanda says:

"In Full House, we can see some young people call their older brother by mentioning 'oppa'. In Padang, this is same as "Uda" or "Ajo". It is different from Western people who call their older brother by mentioning their name directly" (Personal Interview, May 25th, 2018).

The above findings indicate that young Muslim audiences of Korean TV dramas in Indonesia refer to Islamic values when they watch or consume representations of Korean TV dramas. Islamic values are generally socialized by their parents, teachers and preachers. In Padang and Pekanbaru, marriage which should not be based on a certain time contract, for instance, is understood by young Muslims since their basic education in school. They generally learn this from the Fiqh (Islamic jurisprudence) subject. However, they also understand that respecting older people by mentioning 'oppa' is encouraged because it is in proximate with their own culture. In Padang, ' $u d a^{\prime}$ or 'ajo' is used to call males and 'uni' is mentioned for females. This is commonly socialized in their environment to show their respect for older people. Respecting older people is acceptable in Islam. These young Muslims are taught about this value both in their family and school. In a formal school, they are given this value from the Akhlak (moral) subject. Riska, another young audience of Korean TV drama in Pekanbaru, tells:

"in Full House, I was informed about being independent. In the drama, Ji-Eun is an independent woman because she does not stay with her parents. She also works to support her own life as a scriptwriter" (Personal interview, June 17th, 2018).

Islam actually also teaches young Muslims about being independent. This is because it can help to reduce the burden of their parents. It is not surprising that some young Muslims in Pekanbaru work part-time while they are studying in universities. For them, reducing the burden of their parents is encouraged in Islam so that they get rewards (pahala) from God.

However, the representations of "Full House" are not wholly accepted. One of them is a representation of a couple living together in the same house although, in this drama, they truly got married based on a one-year contract. In Islam, they are still regarded as an unmarried couple. In Pekanbaru and Padang, it is called "Kumpul Kebo" (living together without getting married or getting married based on certain time contract). This is forbidden in Islam so that they reject this representation. This indicates that representations of Korean TV dramas are negotiated. Young consumers or audiences actively interpret the representations based on their Islamic values. Anjas says: 
"I disagree with Han Ji- Eun and Lee Young-Jae living together in the same house. They are an unmarried couple so that they are forbidden living like that. It is called Kumpul Kebo" (Personal interview, June 28th, 2019).

In 2019, another Korean television drama was screened on TransTV starting from April 15th 2019 to May 4th 2019 entitled "My ID is Gangnam Beauty". This television drama tells about a woman named Kang Mi-Rae who does not have self-confidence due to her ugly face. She is a shy girl. Because of her ugly face, she is bullied by her classmates. Looking at this condition, her mother then supports her to conduct plastic surgery. After conducting plastic surgery, her face changes to be pretty. Due to her new face, her classmates call her "Gangnam Beauty". Damayanti, an informant in Pekanbaru, states:

"I feel pity to Kang Mi-Rae because she is bullied by her classmates. However, I disagree with her action doing plastic surgery. It is true that it brings a positive impact on her. But, you should not do that though you are ugly. It is forbidden in Islam. When you conduct plastic surgery, it means that you do not thanks to God" (Personal interview, June 30th, 2019).

However, this television drama provides some values compatible with Islam. The story depicts the spirit of a mother supporting her daughter. For young Muslims, this attitude is acceptable except for her support to her daughter to conduct plastic surgery. Ideally, her mother gives a positive suggestion by stopping her to conduct forbidden actions. Therefore, a mother has an important position in Islam. However, they understand that doing plastic surgery is acceptable in Korean culture.

Although there are some representations of the drama contradictory with Islam, another informant in Padang, Rina, considers that "My ID is Gangnam Beauty" can temporarily refresh her mind from the problems she faces in everyday life. Therefore, through consuming the Korean television drama, she can get involved in something that is both fun and 'learning'. She expresses:

"I think Korean television dramas can refresh my mind. Sometimes, I look for something entertaining after learning a lot of things that stress me out. When I watch Korean television dramas, I feel refreshed because when I watch something funny I can laugh and be free of any burden" (Personal interview, May 25th, 2019).

In this context, the notion of 'active' audience does not necessarily emphasize that audiences or consumers are immune to any media influence (Chopra, 2011). This notion fundamentally rejects that 'audience' has directly received the messages sent by the media. This is because 'audiences' can take up the meanings from the symbolic text sent by media based on their everyday relationship. Fiske $(2005$, p.3) argues that "this activation of the meaning potential of a text can occur only in the social and cultural relationships into which it enters. The social relationships of texts occur at their moment of reading as they are inserted into the everyday lives of the readers." Therefore, although Korean television drama has provided an unreal world, Rina agreed that this Korean cultural product is able to provide a momentary comfort from the pressures of her daily life. In addition, for other informants, 
Korean television drama gives Indonesian youths to dream of cool and cute boys. This can refresh young people after experiencing problems at school, university or at work.

Other youths think that Korean television dramas are very valuable because they are able to produce and create strong male and female characters. This can be seen from the representation depicted on a Korean TV drama entitled "Sky Castle". This television drama was broadcasted on TransTV starting from April 15th, 2019. This drama tells about the struggle of housewives or mothers to support their children education. They fight for their children to be accepted in a reputable university in South Korea. This representation has inspired Musfy, a Muslim university student in Pekanbaru. These characters can be used as important references in their daily interactions. These characters are mostly identified as strong because they struggle hard to achieve their ambitions. Musfy says:

"the story touches me. Being strong is needed to reach the goals of life. Furthermore, this drama also teaches me about the importance of education because education supports your career in future" (Personal interview, June 18th, 2019).

The comment above indicates that there are some moral values that are portrayed in Korean television dramas that may not be obtained in their formal education, and can be used by their audience in handling everyday problems. This interpretation is relevant because most characters, both men and women, in Korean television dramas show their strong personalities in trying to achieve their goals.

Muslim youth interpret "stories" in Korean TV dramas by relating them to Islamic values. Some stories that illustrate the struggle of life are direct and Islamic for them. This is because they also struggle to have a better future in life. Some of them are still studying at school or university, while others are struggling to get a job. In Korean television dramas, feelings of strong family relationships are often portrayed, and this is something that correlates with Islamic values.

This means that the possibility of transnational cultural products in spreading "Islamic" values is clear. There are certain scenes depicted in Korean television dramas that can provide Islamic values for young Indonesian Muslims. This is because young Muslims always negotiate representation of Korean television dramas. They study several Islamic values such as aspects of hard work, which are often portrayed in television dramas. Being a devout young Muslim on the one hand and being successful in their future careers is the ultimate goal of those who need hard work. Learning from Korean television dramas, young people have come to understand that to be a successful individual, one must never give up and be discouraged.

Similarly, Appadurai proposes the agency as the notion which supports the active audience concept. Even, rather than receiving the meaning sent by the media, consumer or audience can resist and oppose it. Consuming media programs such as Korean television dramas provides pleasure for the consumers, but this pleasure is not an opium for them. Appadurai (1998, p.7) states:

"when there is consumption there is pleasure, and when there is pleasure there is agency." 
Getting pleasure which is influenced by the media for instance can be different from one audience to another since they have different social and cultural backgrounds. Intan, for instance, says:

"I watch Korean television dramas because their actors are handsome and cute. I do love them. Before I watch the drama, I looked at the actors first. If the actors are handsome and they are my idols, I will watch it. So, for me, I do not take care about the story. The most important thing is the actors of the drama" (Personal interview, May 18th 2019).

The above statement indicates that pleasure has been vital in developing the intimate relationship between audiences and Korean TV dramas. However, this pleasure is also negotiated depending on the motive and personality of audiences. The main motive is that they enjoy with television programs and discover their characters pleasurable. Shyness and loneliness in the audience's life can be a factor contributing to the emergence of pleasure. This pleasure ends when the audience stop consuming a television program because it is an entirely one-sided relationship. When the audience does not like the character is seen in a television drama that changed to be an 'evil', this audience can terminate the relationship by not viewing it. As a result, Korean TV dramas are 'ephemeral' products for Indonesian young Muslims. It is unsurprising that their goal is to capture the pleasure of audiences by any means. As popular culture products, they have some characteristics like instant and temporary (Setyowati, Setiawan, \& Nora, 2012, p. 12-13).

This study shows that young Indonesian Muslims do not passively accept all messages conveyed by the media such as Korean television dramas. Indonesian Muslim youth have an innate cultural identity and conscious knowledge, which they have obtained from their learning environment (eg. education) and culture. Scholars call this an active audience. In this case, Paul Willis $(1998$, p.550) states that consumerism must now be understood as an active, not a passive process. While watching Korean television dramas, young Muslims were able to identify elements of Islam and 'non-Islam', both of which attracted the interest of young people in these dramas. In essence, the representations of Korean drama are always negotiated by Indonesian young Muslims. During the consumption of Korean television dramas, young Muslims are able to negotiate and fight over the values of television dramas. This means that the popularity of the emerging Korean pop culture is a battleground and negotiation between the audience and the producer.

\section{CONCLUSION}

Theoretically and empirically the grand theory of cultural imperialism can always be revisited and contested, especially in cultural studies. The transnational cultural products inflows have contributed to the fear of foreign cultural invasion, especially from the west. In fact, globalization of media also has supported the plurality of cultural producers and centres which can be from East Asian and South Asian countries. Furthermore, the position of consumers or audiences is central in selecting and consuming the cultural products which are relevant to them.

The emergence of transnational cultural products has been believed to play an important role in the process of 'cultural imperialism' among local people. They argue that the information and views presented are not considered to be a 'healthy' menu for Muslim youth. In fact, in cultural studies, media imperialism or cultural imperialism is famously 
contested. This theory assumes that media consumers are passive consumers. Muslim youth received all the messages from the media passively and tend to behave the messages and media display in their daily life. In fact, media consumers have a cultural identity 'innate' attached as well as cognitive knowledge gained from the learning environment and culture. This is called among scholars as an agency since they are active audiences or consumers.

During their consumption on Korean television dramas, young Muslims are negotiating their representations. They are capable of selecting values from the television dramas. These Muslim consumers in this context do not just swallow all the messages and representations of Korean television dramas. It is unsurprising that consumers are able to oppose to some representations of Korean television dramas. This is because these representations contradict with cultural experience and identity which is inherent in them. From the study, it was found that Islamic identity has a crucial role to select the good and bad values from Korean television dramas. It is actually inherent in the spirit of Muslim youth when they are consuming Korean television dramas.

It is the fact that the existence of transnational cultural products could spread pornography, but certain transnational cultural products also could make Muslim youth more Islamic. In fact, through Korean television dramas, Indonesian youth are learning for some values which cannot be gotten from their formal education. They are learning about being hard workers for instance which is often depicted on the television dramas. Being a devout young Muslims on the one hand and to be successful in their careers in the future are their main ideals that require hard work. Learning of Korean television dramas, young people have understood that becoming a modern look should not leave their local cultural traditions.

However, Korean TV dramas are popular culture products. Pop or popular culture is famous but it can be momentary. In this case, the role of consumers is central. They can stop consuming popular cultural products anytime when they no longer love consuming the products. And with the advance of technology, these consumers to some extent are able to consume these cultural products anytime and anywhere at a low economic cost. Further study on this issue is important to be discussed because Korean TV dramas may no longer be screened on Indonesian television. As a result, Indonesian audiences may use the internet by downloading them to watch Korean TV Dramas instead of television.

\section{BIODATA}

Imron Rosidi is the Head of Da'wah Management Department at The Faculty of Da'wah and Communication, State Islamic University of Sultan Syarif Kasim Riau, Indonesia. His research interest area is popular culture, da'wah and media, Muslim youth and religious authority in Indonesia. He got his PhD from the Institue of Asian Studies, Universiti Brunei Darussalam. Email: imronrosidi@gmail.com

Khotimah is a teaching staff at the State Islamic University of Sultan Syarif Kasim Riau, Indonesia. She is also the Head of Religious Studies Department at this university. Her research interest area is Islamic education, media and politics, and religious issues. Email: khotimah@uin-suska.ac.id 


\section{REFERENCES}

Appadurai, A. (1998). Modernity at large: Cultural dimensions of globalization. Minneapolis: University of Minnesota Press.

Astuti, L. D. P. (2012). Imperialisme budaya industri dunia hiburan Korea di Jakarta: Studi terhadap remaja-remaja Jakarta yang menggemari musik pop Korea (Master Thesis, Depok: Universitas Indonesia).

Astuti, L. D. P. (2019, September 7). Ustaz Abdul Shomad: Penonton drama Korea bagian dari kafir. Retrieved from https://www.viva.co.id/showbiz/gosip/1178395-ustaz-abdulsomad-penonton-drama-korea-bagian-dari-kafir

Barker, C. (2000). Cultural studies: Theory and practice. London: Sage.

Chopra, R. (2011). Introduction: Media, culture, and identity in the time of global. In R. Chopra and R. Gajjala (Eds.), Global media, culture, and identity: Theory, cases, and approach (pp. 1-16). London: Routledge.

Chua, B. H., \& Iwabuchi, K. (Eds.) (2008). Introduction: East Asian TV Dramas: Identifications, sentiments, and effects. In, East Asian pop culture: Analysing the Korean wave (1 ed., pp. 1-12). Aberdeen Hong Kong: Hong Kong University Press.

Chua, B. H. (2008). Structure of Identification and Distancing in Watching East Asian Television Drama. In B. H. Chua \& K. Iwabuchi (Eds.), East Asian TV dramas: Analysing the Korean wave (pp. 73-90). Hongkong: Hongkong University Press.

Dwihadiah, D. L. (2015). Media dan imperialisme budaya: Studi pada subkultur penggemar KPop di Indonesia (PhD Dissertation, Depok: Universitas Indonesia).

Fiske, J. (2005). Reading the popular. London: Routledge.

Defleur, M., \& Ball-Rokeach, S. (1989). Theories of mass communication. New York: Longman.

Goodman, D. J., \& Cohen, M. (2004). Consumer culture: A reference handbook. California: $\mathrm{ABC}-\mathrm{CLIO}$.

Hammersley, M., \& Atkinson, P. (2007). Ethnography: Principles in practice. London: Routledge.

Han, B. M. (2019). Fantasies of modernitiy: Korean TV dramas in Latin America. Journal of Popular Film and Television, 47(1), 39-47.

Ida, R. (2008). Consuming Taiwanese boys culture: Watching Meteor Garden with urban kampung women. In A. Heryanto (Ed.), Popular culture in Indonesia: Fluid identities in post-authoritarian politics (pp.93-110). London: Routledge.

Lu, J., Liu, X., \& Cheng, Y. (2019). Cultural proximity and genre proximity: How do Chinese viewers enjoy American and Korean TV dramas?. Sage Open, 9(1), 1-10.

$\mathrm{Ng}$, T-M. \& Chan, C-S. (2020). Investigating film-induced tourism potential: The influence of Korean TV dramas on Hong Kong young adults. Asian Geographer, 37(1), 53-73.

Milestone, K., \& Meyer, A. (2012). Gender and popular culture. New York: Polity Press.

Monaco, P. (2000). Understanding culture, society, and television. London: Praeger.

Oh, I. (2017). Islam and local culture: The peril of state violence and hallyu fandom in Indonesia (with Reference to Palestine). Kritika Kultura, 29, 232-257.

Pawanteh, L., Rahim, S. A., \& Ahmad, F. (2009). Media consumption among young adults: A look at labels and norms in everyday life. Jurnal Komunikasi: Malaysian Journal of Communication, 25, 21-31.

Pieterse, J. N. (1995). Globalization as hybridization. In M. Featherson, S. Lash, \& R. Robertson (Eds.), Global modernities (pp.45-68) London: Sage Publications. 
Putri, V. K., \& Reese, M. (2016). The impact of Korean wave on young Indonesian females and Indonesian culture in Jabodetabek area. Bussiness and Management Studies Journal, $3(2), 35-53$.

Salim, D. P. (2015). The transnational and the local in the politics of Islam. London: Springer. Setyowati, R. M., Setiawan, Y. B., \& Nora, H. Y. (2012). Mencari nilai hormat dan rukun pada tayangan opera Van Java Trans 7. The Messenger, IV(1), 1-15.

Storey, J. (2003). Cultural studies and the study of popular culture. Edinburgh: Edinburgh University Press.

Takahashi, T. (2010). Audience studies: A Japanese perspective. Routledge: London.

Tomlinson, J. (2001). Cultural imperialism. London: Continuum.

Willis, P. (1998). Symbolic creativity. In J. Storey (Ed.), Cultural theory and popular culture: A reader. London: Prentice Hall. 